\title{
Users' psychological characterization of the Birigui Mental Health Clinic
}

\author{
Caracterização dos usuários do atendimento \\ psicológico do Ambulatório de \\ Saúde Mental de Birigui
}

\author{
Renato Salviato FAJARDO' \\ Adriana Cristina ZAVANELLI ${ }^{1}$ \\ Eliene Ferreira BOTASIM ${ }^{2}$ \\ Glaucia de Souza BARBOZA ${ }^{2}$
}

\begin{abstract}
To improve mental health services, the World Health Organization proposes an "epidemiological approach" based on the constant screening of existing research, and aimed at continuous improvement of psychological treatment rather than strict application of prescribed techniques. This study provides an epidemiological survey conducted at the psychology ward of the municipal Ambulatório de Saúde Mental in Birigui, São Paulo, Brazil. Data from 180 patients in psychotherapeutic care were collected, and subsequent descriptive analysis showed that the population consisted predominantly of adults (82.8\% of total) and females (81.0\%). Depressive disorder was the most common symptom $(61.1 \%)$, and the majority of the participants $(72.2 \%)$ received psychological treatment for the first time. The data presented in this paper can assist mental health professionals in selecting appropriate treatment by creating a profile of patients.
\end{abstract}

Keywords: Depression; Gender identity; Health profile; Mental health; Psychic symptoms.

\section{Resumo}

Segundo a Organização Mundial de Saúde, a fim de se aprimorarem os serviços de saúde mental, são necessários investimentos na produção de dados concretos sobre os serviços e os recursos existentes. Para cumprir essa orientação, é imprescindível uma "atitude epidemiológica", de forma a não permitir que o trabalho se restrinja apenas à aplicação de técnicas, mas imponha uma postura de invenção permanente ao lidar com o sofrimento psíquico. Este estudo, que traça o perfil epidemiológico da população que utiliza o serviço de psicologia do Ambulatório de Saúde Mental de

$\nabla \nabla \nabla$

1 Universidade Estadual Paulista Júlio de Mesquita Filho, Faculdade de Odontologia, Departamento de Materiais Odontológicos e Prótese. R. José Bonifácio, 1193, Vila Mendonça, 16015-050, Araçatuba, SP, Brasil. Correspondência para/Correspondence to: A.C. ZAVANELLI. E-mail: <zavanelliac@foa.unesp.br>

2 Psicóloga. Araçatuba, SP, Brasil. 
Birigui São Paulo, foi realizado através de coleta de dados dos prontuários dos pacientes em atendimento psicoterapêutico. Foram pesquisados: idade, gênero, queixa, realização e duração de tratamento psicológico anterior, período do atual tratamento psicológico, forma de encaminhamento ao ambulatório e tipo de tratamento. Segundo os dados, a população atendida foi predominantemente de adultos $(82,8 \%)$ do gênero feminino (81,0\%). 0 sintoma mais comum relatado foi o transtorno depressivo (61,1\%), e a maioria (72,2\%) estava em tratamento psicológico pela primeira vez. Os dados analisados nos permitem concluir que a caracterização dos pacientes auxilia no esboço de um perfil de usuários para orientar e propor atendimentos dos serviços de saúde mental.

Palavras-chave: Depressão; Identidade de gênero; Perfil de saúde; Saúde mental; Sintomas psiquicos.

A municipal Ambulatório de Saúde Mental (ASM, Mental Health Clinic) is a specialised outpatient facility aimed at providing treatment, rehabilitation and social insertion, as well as promoting mental health. It generally targets the whole population, including children and adolescents.

The Mental Health Clinic in Birigui (SP) opened on 18 August 1990, in the period of psychiatric reform. At the moment this study was conducted, the unit had a total of 15,000 patients on file, of which 2,500 active. A specific service exists for the treatment of children, which means that the Mental Health Clinic mainly attends adults and adolescents (Birigui, 2009; Hirdes, 2009).

Various studies have researched the characteristics of treatment of adolescents (Barbosa, 1992; Schoen-Ferreira, Silva, Farias, \& Silvares, 2002), considering the transformations that this phase involves. Studies with adult subjects, on the other hand, point mainly to personal conflicts as a result of physical and/or emotional transformations (Mori \& Coelho, 2003, 2004; Mori, Coelho, \& Estrella 2006). However, few of these private experiences appear to reach public health services. Knowledge in the public health sector seems to be based for the most part on practical work experience of the professionals involved, and is therefore imprecise and not generalisable. It was verified that the development of services lacks parameters and systemisation, and that incentives and investments in research to improve offered services are scarce (Arcaro, 1991). Mental health services in municipal clinics have, according to official reports, a low success rate and limited impact on the larger mental 108 health network (Brasil, 2010a).
The World Health Organization urges that investments in research on existing services and resources are necessary in order to improve mental health services. In this context, it is important to adopt an epidemiological attitude, consisting of constant assessment of the mental health state of the population, its evolution and what it is affected by. This approach ensures that services aren't restricted to the application of techniques, but involve a posture of permanent intervention in dealing with psychic suffering (Brasil, 2010b; Paraná, 2010; Santa Catarina, 2004). Knowledge of patients' complaints and demands also assists in improving the planning and organisation of preventive and curative action (Gatti \& Beres, 2004; Peres, Santos, \& Coelho, 2004; Romaro \& Capitão, 2003).

The objective of this study is to propose an epidemiological characterisation of the patients of a mental health centre in Birigui, a medium-sized city in the state of São Paulo, thus contributing to the implementation of new strategies aimed at serving users of mental health services in a more effective way.

\section{Method}

\section{Participants}

This study is based on the collection of data from patient files of 180 patients receiving psychotherapeutic care at the Birigui mental health centre in the period 2009-2010. All participants gave informed consent, after which the data were collected by the psychologists responsible for the treatment. Doctor-patient confidentiality was observed, considering that the study is about 
documenting differential activities (Franco \& Mota, 2003).

\section{Instruments}

Following approval by the Human Ethics Committee of the Faculdade de Odontologia de Araçatuba (FOA, Dentistry School of Araçatuba) (Process $\left.n^{\circ} 00885 / 2010\right)$, the following data were recorded: age, gender, complaint (reason for the patient seeking assistance), prior psychological treatment and its duration, present treatment time and referral path to the facility.

\section{Proceedings}

Data about medical complaints were collected from patients' intake charts, where the results of screening interviews are recorded. As such, this study does not aim to present full diagnoses, but rather the reasons for which the patients seeked assistance. Medical diagnoses were only used in cases where those were present on the intake charts.

In order to facilitate systemisation and interpretation of data and avoid fragmentation of the patient group in many different categories, complaints were grouped according to criteria defined by the Diagnostic and Statistical Manual of Mental Disorders - DSM-IV-TR, without the pretention of making diagnostics, as applied in earlier work (Jorge, 2002). In addition, the following categories better fit into criteria established by Campezatto and Nunes (2007), Louzada (2003), and Romaro and Capitão (2003):

- Symptoms of depressive disorder: Sadness/ anguish, forgetfulness, irritability, insecurity/low selfesteem, sleep disorder, increase or loss of appetite, headache, compulsive crying, weariness, desire to disappear, suicidal tendency, suicide attempt and psychotic symptoms (Jorge, 2002).

- Symptoms of anxiety disorder: Anxiety, shortness of breath, perspiration, trembling, concern with physical health, tingling sensation, cold hands, pressure on the chest, faintish feeling, tachycardia, changes in blood pressure, xerostomia, fear and phobia; among which fear of being alone, going up stairs, using lifts, driving, or dying (Jorge, 2002; National Institute of Mental Health, 1991; Silva, 2006), obsessive compulsive disorder, ritualism, recurring negative thoughts, compulsion towards certain behaviours, post-traumatic stress symptoms related to anguish, anger, despair, crying, physical symptoms, insomnia and delusions of persecution related to a traumatic event (Jorge, 2002; Torres \& Smaira, 2001).

- Difficulties in interpersonal relationships: Family and marital conflicts, difficulty with interpersonal relationships in general, shyness, jealousy, aggression, impulsivity and guilt (Cerchiari, Caetano, \& Faccenda, 2005; Louzada, 2003; Portugal, 2008; Romaro \& Capitão, 2003).

- Physical disease: Heart problems, hypertension, diabetes, lupus, cancer, obesity and headaches (Campezatto \& Nunes, 2007).

- Grief: Loss by death or separation (Louzada, 2003).

- Alcohol and/or drug abuse

- Others: Less common complaints and disorders, such as: bipolar affective disorder (medically diagnosed), smoking, sexual abuse and sexual dysfunction.

Registered adolescent-specific complaints were: Indiscipline, learning difficulties, distractedness, stealing, enuresis, and stuttering (Schoen-Ferreira, et al., 2002).

After the data from the medical records were grouped according to the above parameters, a descriptive analysis was performed in order to obtain group percentages and enable comparison.

\section{Discussion}

The patient's characterisation with regard to gender, it was observed that a majority of $81 \%$ of all patients were female, with $19 \%$ male patients (Table 1).

The high percentage of female patients in mental health services corresponds with finds in 
Table 1

Number of patients by gender and age. Birigui (SP), 2010

\begin{tabular}{lcc}
\hline \multirow{2}{*}{ Description } & \multicolumn{2}{c}{ Patient } \\
\cline { 2 - 3 } & $\mathrm{n}$ & $\%$ \\
\hline Female patients & 146 & 81.0 \\
Male patients & 34 & 19.0 \\
Patients aged 40 to 49 & 44 & 24.4 \\
Patients aged 50 to 59 & 32 & 17.8 \\
Patients aged 60 to 66 & 14 & 7.8 \\
Total adult patients & 149 & 82.8 \\
Total adolescent patients & 31 & 17.2 \\
\hline
\end{tabular}

other studies (Cerchiari et al., 2005), and may be interpreted as a manifestation of sociocultural patterns in gender relations. Prevailing behavioural standards dictate, for instance, that women are expected to externalise their emotions, seeking assistance when necessary, whereas men are expected to hide emotions and psychic distress when dealing with the difficulties that arise in daily life, thus cultivating an image of courage, strength and stability (Peres et al., 2004).

It can be observed that patients aged 40 to 49 make up the largest age group (24.4\%), followed by patients aged 50 to 59 (17.8\%). Both age groups have a female majority. Table 1 also shows a considerable majority of adults in the population $(82.8 \%)$, compared to $17.2 \%$ adolescents. It may be assumed that the predominance of women in the age category of 40 to 59 years is associated to the climacteric period. Although it is beyond the scope of this study to confirm this assumption, it is clear that the climacteric has a profound influence on symptoms of anxiety and depression, which can urge people to seek medical and psychotherapeutic assistance. A study conducted by Pedro, Pinto-Neto, Costa-Paiva, Osis, and Hardi (2002) with female patients aged 45 to 60 revealed a high occurrence of climacteric symptoms, the most frequent of which were considered by the authors to be of psychological nature, including depression, nervous tension and irritability.

Menopause is characterised by biological, psychological and sociocultural aspects, and requires some restructuring in the psychological framework 110 of middle-aged women (Mori \& Coelho, 2004). It is in this context that psychosocial factors act that can intensify emotional reactions. The phase in which menopause occurs often coincides with other big changes, such as retirement, children leaving home, elderly parents, and a worn-out conjugal relationship. These events can in some cases culminate into separation or being widowed (Mori \& Coelho, 2003).

In the light of earlier research and the data gathered in this study, the proposal by Mori and Coelho (2003) about the importance of psychological assistance in public health services is considered highly relevant.

Another striking detail that came forward in the present study is the near absence of elderly patients. Patients aged 60-66 corresponded with $7.8 \%$ of the total, with the oldest patient being 66 years old (Table 1). The absence of elderly patients in mental health services was also emphasised by Louzada (2003).

Data from Table 2 point out that the largest group of patients, $41.1 \%$ of the population, were referred to the mental health facility by medical practitioners at Unidade Básica de Saúde (UBS, Basic Public Health Units). Another 15.5\% were referred by medical specialists, whereas $12.2 \%$ were referred by acting professionals at the mental health centre itself. This distribution reveals that the clinic functions well within the public network, and that it receives patients through referrals by UBS, psychiatric hospitals, schools, courts, tutelary councils, psychotechnic services and other institutions, with the exception of urgent cases and emergencies, which receive immediate attention.

Table 3 below shows patients' history of prior psychological treatment. It can be seen that $72.0 \%$ of all patients have no history of psychological treatment. Of the patients that were subjected to treatment $(27.8 \%)$ before, treatment periods varied from 6 months (26.4\%) to one year (24.5\%).

Of the patients receiving treatment at the moment the sample was taken, $40.6 \%$ had been treated for 1-6 months, whereas $17.8 \%$ had been treated for over 1 but less than 2 years. Another $17.8 \%$ had been treated for over 2 years. 
Table 2

Referral path to the Mental Health Clinic. Birigui (SP), 2010

\begin{tabular}{llc}
\hline \multirow{2}{*}{ Description } & \multicolumn{2}{c}{ Patient's referred } \\
\cline { 2 - 3 } & $\mathrm{n}$ & $\%$ \\
\hline Referred by UBS & 74 & 41.1 \\
Referred by medical specialists & 27 & 15.5 \\
Referred by the Clinic's own personnel & 22 & 12.2 \\
\hline
\end{tabular}

Note: UBS: Unidade Básica de Saúde.

Table 3

History of psychological treatment. Birigui (SP), 2010

\begin{tabular}{lcc}
\hline \multirow{2}{*}{ Description } & \multicolumn{2}{c}{ Prior treatment number } \\
\cline { 2 - 3 } & $\mathrm{n}$ & $\%$ \\
\hline Never had psychological treatment & 130 & 72.0 \\
Had psychological treatment & 50 & 27.8 \\
Duration of treatment 6 months & 13 & 26.4 \\
Duration of treatment 1 year & 12 & 24.5 \\
Patients in treatment 1-6 months & 73 & 40.6 \\
Patients in treatment 1<2 years & 32 & 17.8 \\
Patients in treatment >2 years & 32 & 17.8 \\
\hline
\end{tabular}

\section{Table 4}

Number of cases per type of complaint. Birigui (SP), 2010

\begin{tabular}{lcc}
\hline \multirow{2}{*}{ Description } & \multicolumn{2}{c}{ Patient's symptoms } \\
\cline { 2 - 3 } & $\mathrm{n}$ & $\%$ \\
\hline Symptoms of Depressive Disorder & 110 & 61.1 \\
Difficulty in interpersonal relationships & 97 & 53.8 \\
Symptoms of Anxiety Disorder & 84 & 46.6 \\
\hline
\end{tabular}

This result may be related to a commonly held belief that the Ministry of Health established a maximum of 6 months for the duration of psychological treatment in the public sector. However, there is no official document present at the institution confirming this norm. From this, it can be inferred that the cases with treatment for more than two years involve grave mental disorders that cannot be resolved in a shorter period.

As is demonstrated in Table $4,61.1 \%$ of the sample population sought psychological assistance as a result of symptoms related to depressive disorder. Furthermore, $53.8 \%$ suffered from difficulties in interpersonal relationships, and another $46.6 \%$ had symptoms of anxiety disorder.
Relating gender with complaints, it was observed that in both genders the prevalence of depressive disorders was the highest, followed by difficulty in interpersonal relationships and anxiety disorder, with equivalent percentages of approximately $36.0 \%$ on the two variables for female and $5.0 \%$ for male patients. This complaint is characterised by: sadness/anguish, forgetfulness, anger, irritability, insecurity/low self-esteem, sleep disorder, increase or loss of appetite, headache, compulsive crying, weariness, desire to disappear, suicidal tendency, suicide attempt and psychotic symptoms.

Analysing the profile of complaints of adolescent patients separately, a particularly high prevalence of difficulty in interpersonal relationships stood out $(43.1 \%)$. This category includes: family and marital conflicts, difficulty with interpersonal relationships in general, shyness, jealousy, aggressiveness, impulsivity and guilt. The presence rate of adolescents (17.2\%) in the patient group points to the importance of adopting a groupspecific psychological approach that takes the critical transformations that occur during adolescence into account (Schoen-Ferreira et al., 2002).

The second most frequent complaint in adolescent patients involved symptoms of anxiety disorder, followed by depressive disorder and learning difficulties, equally distributed.

Research by Romaro \& Capitão (2003) provided similar results; adolescents in their sample predominantly had difficulties in interpersonal relationships (25.4\%), family relations $(22.5 \%)$, learning problems $(9.8 \%)$, sleep disorder, eating disorder, enuresis and difficulty in dealing with loss (8.8\% cumulative).

Then, the characterisation of the epidemiological profile found in the studied population is composed, in majority, of female adults aged 40 to 59 years, referred by practitioners from a UBS, and receiving psychological treatment for the first time, the duration of which varied from 1 to 6 months. Predominant complaints related to 
symptoms of depressive disorder and, in the case of adolescents, difficulty in interpersonal relationships.

The relatively high representation of middleaged women in the Mental Health Clinic's patient file points to the importance of developing programmes that attend to the specific needs of this group. As mentioned before, it is in this phase of life that several psychosocial factors appear that can contribute to emotional problems, such as feeling of abandonment when children leave home, ageing parents, retirement and a worn-out conjugal relationship (Mori \& Coelho, 2003).

For this reason, Mori and Coelho (2003) propose the inclusion of group specific psychological assistance, aimed at improving the quality of life of middle-aged women by helping them redefine their social relations, deal with losses, and redirect time and energy to new goals and pastimes.

This study revealed the necessity to revise and standardise the instruments used at the institution, considering that several variables relevant for research like marital status, occupation, education and address were either unrecorded or recorded in a non-systemised manner. It was also noted that there is a need to improve the files kept on the work and activities of psychologists. At present there is no demand by authoritative organs to provide documentation about anything other than individual and groups consults, which means that no registers are kept on extra activities like waiting room activities and sociocultural activities. Information about this was therefore collected verbally from the clinic's staff members, but if documented systematically it could make an interesting contribution to new research.

Respecting the limitations of this study and considering its context, it can be concluded that information systemisation at mental health clinics is a fundamental factor in generating reliable data needed for the implementation of improvements in mental health care. This way, the visibility and impact of projects is increased, which in turn leads to more recognition by the government and society

112 at large.

\section{References}

Arcaro, N. T. (1991). Investigação de aspectos da clientela e sistema de atendimento de um ambulatório de saúde mental. Psicologia USP, 2(1-2), 49-63.

Barbosa, J. I. C. (1992). Uma caracterização preliminar das clínicas-escola de Fortaleza (Dissertação de mestrado não-publicada). Programa de Pós-Graduação em Psicologia Clínica, Universidade de São Paulo.

Birigui. Prefeitura Municipal. (2009). Relatório de atividades da equipe técnica do ambulatório de saúde mental da prefeitura municipal de Birigui. Birigui: Prefeitura Municipal.

Brasil. Ministério da Saúde. (2010a). O que é reforma psiquiátrica. Recuperado em outubro 5, 2010, disponível em <http://portal.saude.gov.br/portal/saude/ visualizar_texto.cfm?idtxt=33929>.

Brasil. Ministério da Saúde. (2010b). Saúde mental em dados - 7. Brasília: Ministério da Saúde. Recuperado em julho 14, 2010, disponível em <www.saude.gov. $\mathrm{br} / \mathrm{bvs} /$ saudemental>.

Campezatto, P. M., \& Nunes, M. L. T. (2007). Caracterização da clientela das clínicas-escola de cursos de Psicologia da região metropolitana de Porto Alegre. Psicologia: Reflexão e Crítica, 20(3), 376-388.

Cerchiari, E. A. N., Caetano, D., \& Faccenda, O. (2005). Utilização do serviço de saúde mental em uma universidade pública. Psicologia Ciência e Profissão, 25(2), 252-265.

Franco, A., \& Mota, E. (2003). Distribuição e atuação dos psicólogos na rede de unidades públicas de saúde no Brasil. Psicologia: Ciência e Profissão, 23(3), 50-59.

Gatti, A. L., \& Beres, V. L. (2004). Queixas em serviço de atendimento psicológico. Integração, 10(38), 281-284.

Hirdes, A. (2009). A reforma psiquiátrica no Brasil: uma (re)visão. Ciência e Saúde Coletiva, 14(1), 297-305.

Jorge, M. R. (2002). Manual diagnóstico e estatístico de transtornos mentais: DSM-IV-TR. Porto Alegre: Artmed.

Louzada, R. C. R. (2003). Caracterização da clientela atendida no núcleo de psicologia aplicada da Universidade Federal do Espírito Santo. Estudos de Psicologia (Natal), 8(3), 451-457.

Mori, M. E., \& Coelho, V. L. D. (2003). A vida ouvida: a escuta psicológica e a saúde da mulher de meia-idade. Estudos e Pesquisas em Psicologia, 3(2). Recuperado em novembro 6, 2010, disponível em <http:// www.revispsi.uerj.br/v3n2/artigos/Artigo\%204\%20$\% 20 V 3 N 2 . p d f>$.

Mori, M. E., \& Coelho, V. L. D. (2004). Mulheres de corpo e alma: aspectos biopsicossociais da meia-idade feminina. Psicologia: Reflexão e Crítica, 17(2), 177-187.

Mori, M. E., Coelho, V. L. D., \& Estrella, R.C.N. (2006). Sistema Único de Saúde e políticas públicas: aten- 
dimento psicológico à mulher na menopausa no Distrito Federal, Brasil. Cadernos de Saúde Pública, 22(9), 1825-1833.

National Institute of Mental Health. (1991). Treatment of panic disorder. NIH Consens Statement, 9(2), 1-24.

Torres, A. L. R., \& Smaira, S. (2001). Quadro clínico do transtorno obsessivo-compulsivo. Revista Brasileira de Psiquiatria, 23(2), 6-9.

Paraná. Conselho Estadual de Saúde. (2010). Organização de serviços de saúde mental. Recuperado em janeiro 25, 2010, disponível em <http://www.saude.pr.gov.br/ arquivos/File/plano_estadual_saude_1104.pdf > .

Pedro, A. O., Pinto-Neto, A. M., Costa-Paiva, L., Osis, M. O., \& Hardi, E. (2002). Procura de serviço médico por mulheres climatéricas brasileiras. Revista de Saúde Pública, 36(4), 484-490.

Peres, R. S., Santos, M. A., \& Coelho, H. M. B. (2004). Perfil da clientela de um programa de pronto-atendimento psicológico a estudantes universitários. Psicologia em Estudo, 9(1), 47-54.
Portugal. Ministério da Saúde. (2008). Plano Nacional de Saúde Mental 2007-2016: resumo executivo. Lisboa: Coordenação Nacional para a Saúde Mental.

Romaro, R. A., \& Capitão, C. G. (2003). Caracterização da clientela da clínica-escola de psicologia da Universidade São Francisco. Psicologia: Teoria e Prática, 5(1), 111-121.

Santa Catarina. Secretaria de Estado da Saúde. (2004). Plano Estadual de Saúde Mental: 2005-2006. Florianópolis: Secretaria de Estado da Saúde.

Schoen-Ferreira, T. H., Silva, D. A., Farias, M. A., \& Silvares, E. F. M. (2002). Perfil e principais queixas dos clientes encaminhados ao Centro de Atendimento e Apoio Psicológico ao Adolescente (CAAA) - UNIFESP/EPM. Psicologia em Estudo, 7(2), 73-82.

Silva, A. B. B. (2006). Mentes com medo: da compreensão à superação. São Paulo: Integrare.

Received on: 26/7/2011

Final version on: 13/4/2012

Approved on: 3/5/2012 
